\title{
FULLY-AUTOMATIC LANDSLIDE SUSCEPTIBILITY ANALYSIS BY GEOGRAPHICAL INFORMATION SYSTEM (GIS): A CASE STUDY IN ŞAVŞAT CITY, TURKEY
}

DOI: https://doi.org/10.18509/AGB.2019.01

UDC: 004:528.88]:551.311.21(560)

Derya Dilara Köse, Tarık Türk

Cumhuriyet University, Faculty of Engineering, Department of Geomatics Engineering, Turkey

corresponding author: tarikturk@gmail.com

\author{
submitted: 25.02 .2018 \\ accepted: 20.05 .2018 \\ published: 01.11.2018
}

\begin{abstract}
In the literature, different methods and parameters were used to produce the most accurate Landslide Susceptibility Map (LSM) in each of the studies. In this study, it was aimed to produce a GIS-based LSM by the The Frequency Rate (FR) method in the selected study area, to calculate the accuracy of the produced LSM and to perform all these operations fully-automatically. In line with this purpose, user-interface programs were developed in the GIS environment. The FR method that is commonly used in the literature and gives high accuracy was used to produce an LSM. Slope, aspect, elevation, lithology, distance to fault, distance to river, Normalized Difference Vegetation Index (NDVI), land use and rainfall parameters were taken into account to produce the LSM. Consequently, the accuracy of the LSM obtained by the FR method was calculated to be $89 \%$.
\end{abstract}

Keywords: GIS, Landslide, Landslide Susceptibility Analysis, User Interface Program

\section{INTRODUCTION}

Natural disasters cause many losses of life and property. One of the natural disasters that cause the loss of life and property in Turkey is the landslide. It is observed that almost every province in Turkey is affected by landslides at certain degrees [1]. The Black Sea region is the most important region where landslide potential is the highest in Turkey. In today's technology, the losses caused by landslides can be decreased by determining the landslide areas and planning the environment accordingly. These areas can be determined by landslide susceptibility analyses. The aim of the landslide susceptibility analysis is to decrease the effects of the landslide by determining dangerous and risky areas [2]. Hazard maps contain information about the identification of natural events and the estimation of the occurrence of such natural events in the future [3]. Therefore, the production of a high quality LSM is very important for natural disaster management. Many different methods are applied for the LSM which is produced via Geographical Information Systems (GIS). There are two basic steps in this process. One of these steps is the selection of the method and the determination of other parameters to be used. When the literature is examined, it is observed that LSMs are produced by applying different methods. Easy to use, and carried out with complex mathematical operations methods have been used. One of the commonly used methods for the preparation of LSM is the GIS-based Multi-Criteria Decision Analysis (MCDA) method [4], [5]. The Logistic Regression (LR) and Geographical Weighted Regression (GWR) [6], Regression Tree (RT) and LR methods have been used recently [7]. Erener et al. [8] created the LSM in Şavşat district of Artvin province using the LR, GIS-based MCDA and Association Rule Mining (ARM) methods. Colkesen et al. [9] compared with the LR method using the kernel-based Gaussian Proces Regression (GPR) and Support Vector Regression (SVR) methods. Chen et al. [10] applied the Naive Bayes Tree (NBTree), Kernel Logistic Regression (KLR) and Alternating Decision Tree (ADTree) methods. The statistical methods commonly used in the literature determine the correlation according to landslide areas by evaluating the factors affecting the landslide. Guzzetti et al. [11] classified the methods by summarizing many studies on landslide susceptibility in the literature. It was stated that probability-based studies were carried out in many of them. One of the statistical methods frequently used in the preparation of LSMs is the LR method 
[6], [12], [13], [14], [15]. Terranova et al. [16] examined the rainfall factor together with other factors with this method. The Frequency Rate (FR) method is a commonly used method that is easily applied and provides high accuracy [17], [18], [19]. In this study, it was aimed to produce a GIS-based LSM using the FR method, which is usually emphasized to give the most accurate result in the literature and to determine its accuracy. The surroundings of Şavşat district of Artvin (Turkey) province, which is one of the regions with the highest landslide risk, was selected as the study area (Fig. 1). Consequently, landslide susceptibility analysis was performed in the study area.

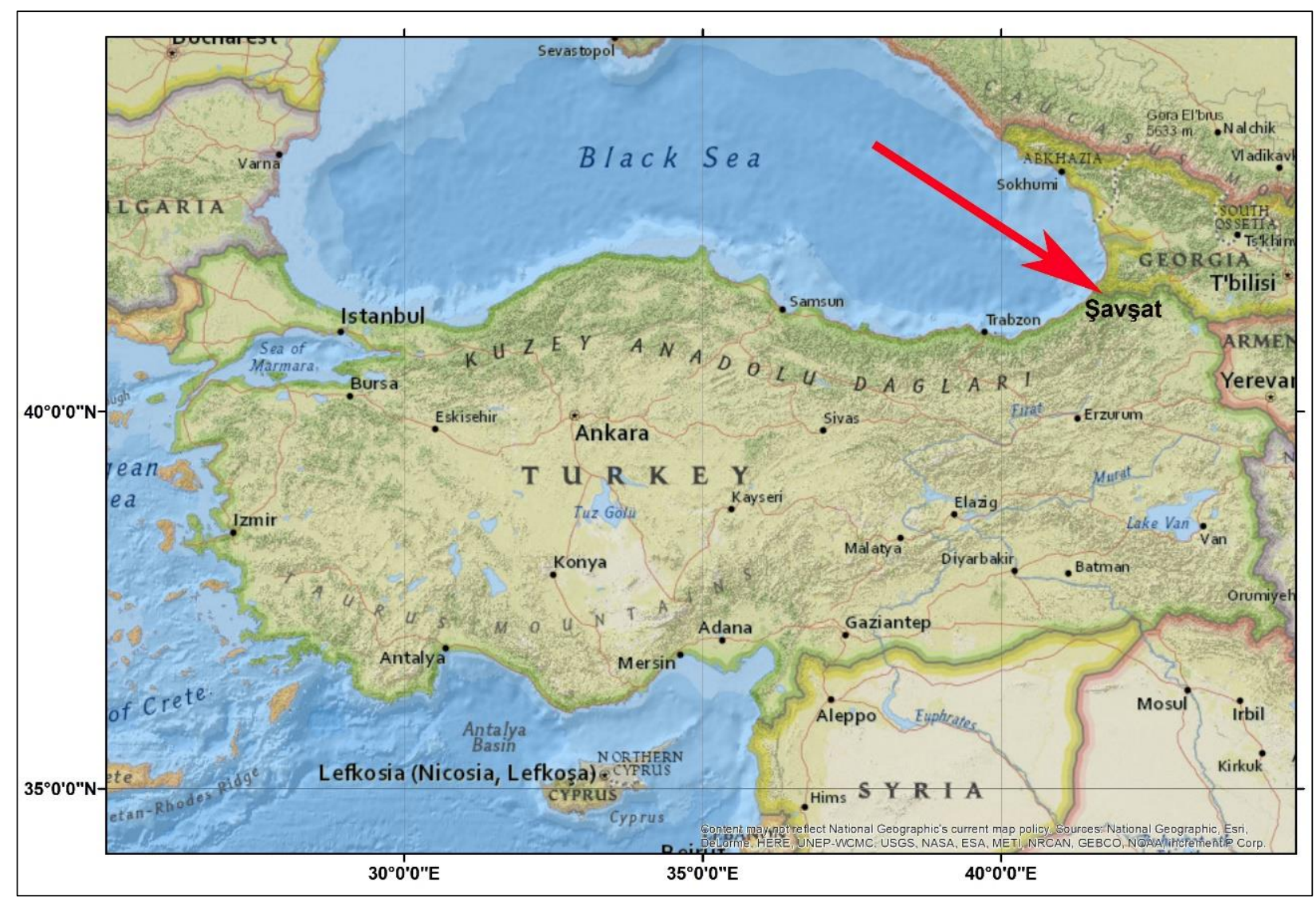

Figure 1. Study Area

One of the most important topographic parameters affecting the formation of landslides is the slope of the land. Areas with more roughness increase the landslide risk. The slope map of the study area was produced in the GIS environment (Fig. 2). Aspect (Fig. 2), which is included in topographic parameters, is one of the important factors affecting the landslide [22], [23]. This parameter should be considered for the landslide susceptibility analysis. The fault map (Fig. 2) produced by MRE [24] was used within the scope of this study. The degree of the saturation of slopes is an important criterion for a landslide (distance to river). The distance of slopes to the river also affects this situation. Rivers cause landslides with erosion on hillsides or slopes, by saturating the substances forming the slopes [25], [26]. The river system of the study area was determined in the ArcGIS 10.3 program using the DEM data (Fig. 2). Land use is among the environmental factors that are mostly affected by environmental factors such people etc. The usage purpose of the land use data is among the important parameters used in applications since it affects the landslides. Therefore, the classification was made using the Landsat 8 (2016) satellite images, and the land use map was created (Fig. 2).

Depending on many parameters such as humidity, vegetation cover, organic matter content, and the season in which the rainfall occurs on slopes with heavy rainfall, the material in slopes with the dominant aspect reaches saturation more quickly compared to other slopes. This also causes pore water pressure to reach saturation [27]. 


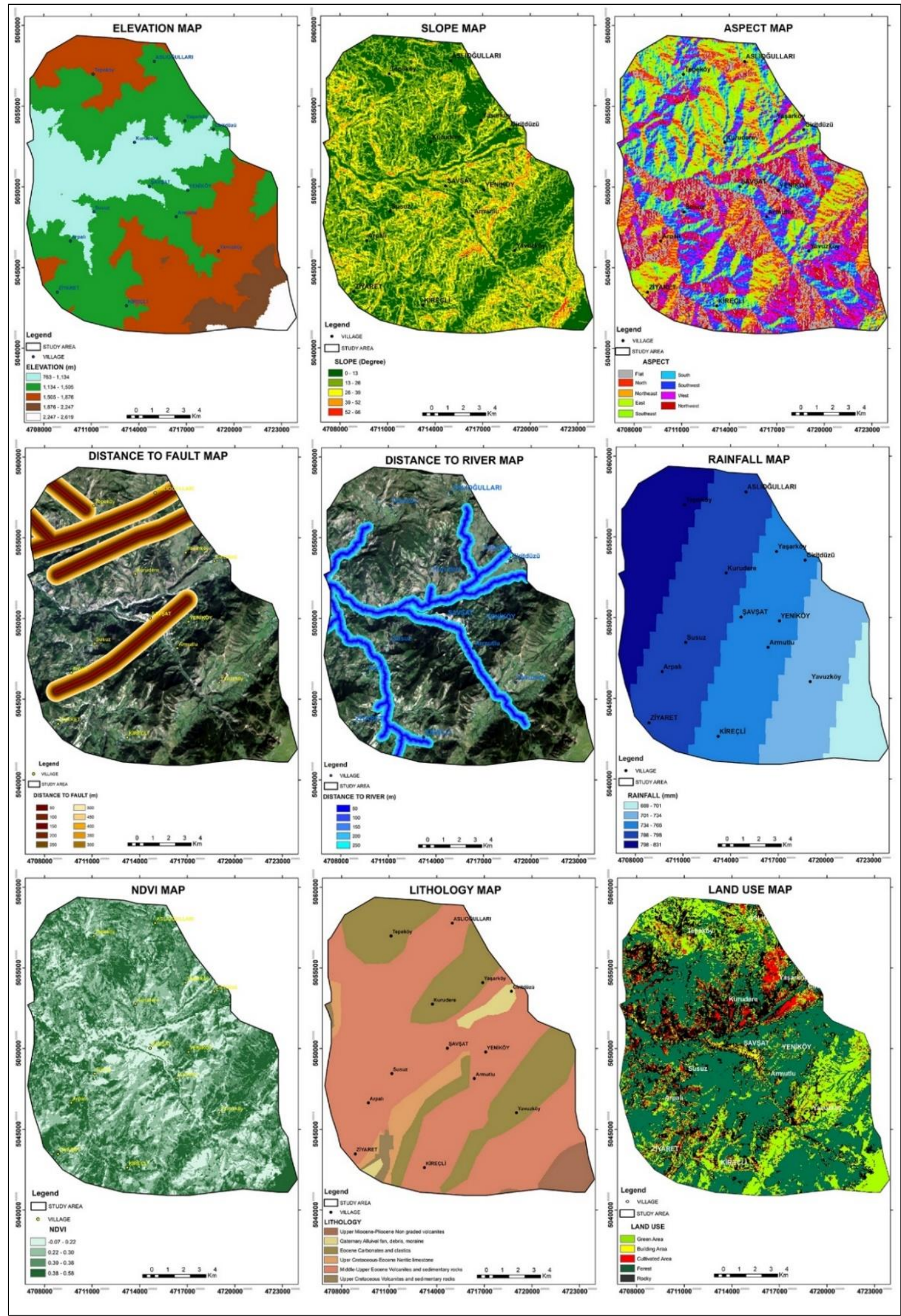

Figure 2. Factor maps

Accordingly, the risk of landslide increases. The Black Sea region, where the study area is located, is a region exposed to heavy rainfall in the climatic sense, and the rainfall factor was taken into account because landslide incidents are more frequently observed on rainy days (Fig. 2). Another parameter which was considered in the study is lithology (Fig. 2). This parameter, which is among the geological factors, is an important parameter commonly used for landslide formation because the structures with 
different features have different susceptibility for landslide formation. Vegetation (Fig. 2) is among the important environmental factors used to investigate landslide susceptibility as it retains the soil. In particular, it prevents soil from sliding in sloped areas.

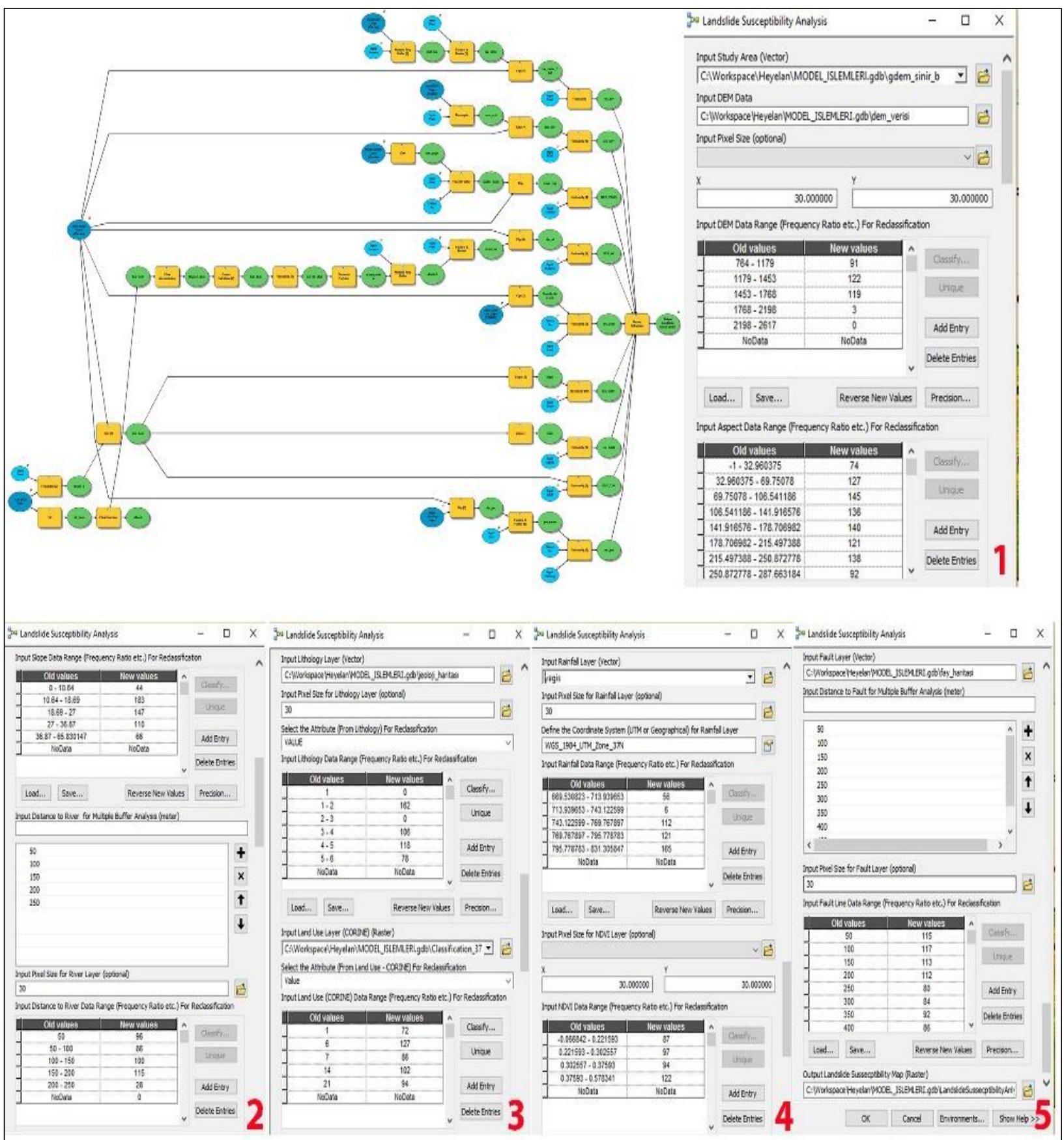

Figure 3. The user interface program developed for producing the LSM

\section{Production of the LSM}

\section{Using the Frequency Ratio Method}

The frequency ratio method is applied by investigating the relationship between past landslide locations and the subclasses of each factor. In this method, the relationship of the subclass with the landslide inventories is used.The
FR values are calculated. Then, these calculated values are transferred to the GIS environment. The LSM is created using the FR values. The LSM is obtained by calculating the Landslide Susceptibility Index (LSI) by adding the FR values assigned to each layer one after the other.

LSI $=$ FRslope + FRaspect + FRelevation + FRfault + FRriver + FRndvi + FRlithology + FRland use + 
The accuracy of the LSM created should be calculated. The accuracy analysis was performed with the test landslides that were determined at the very beginning of the study. LSM's "high" and

"very high susceptible" classes were used.

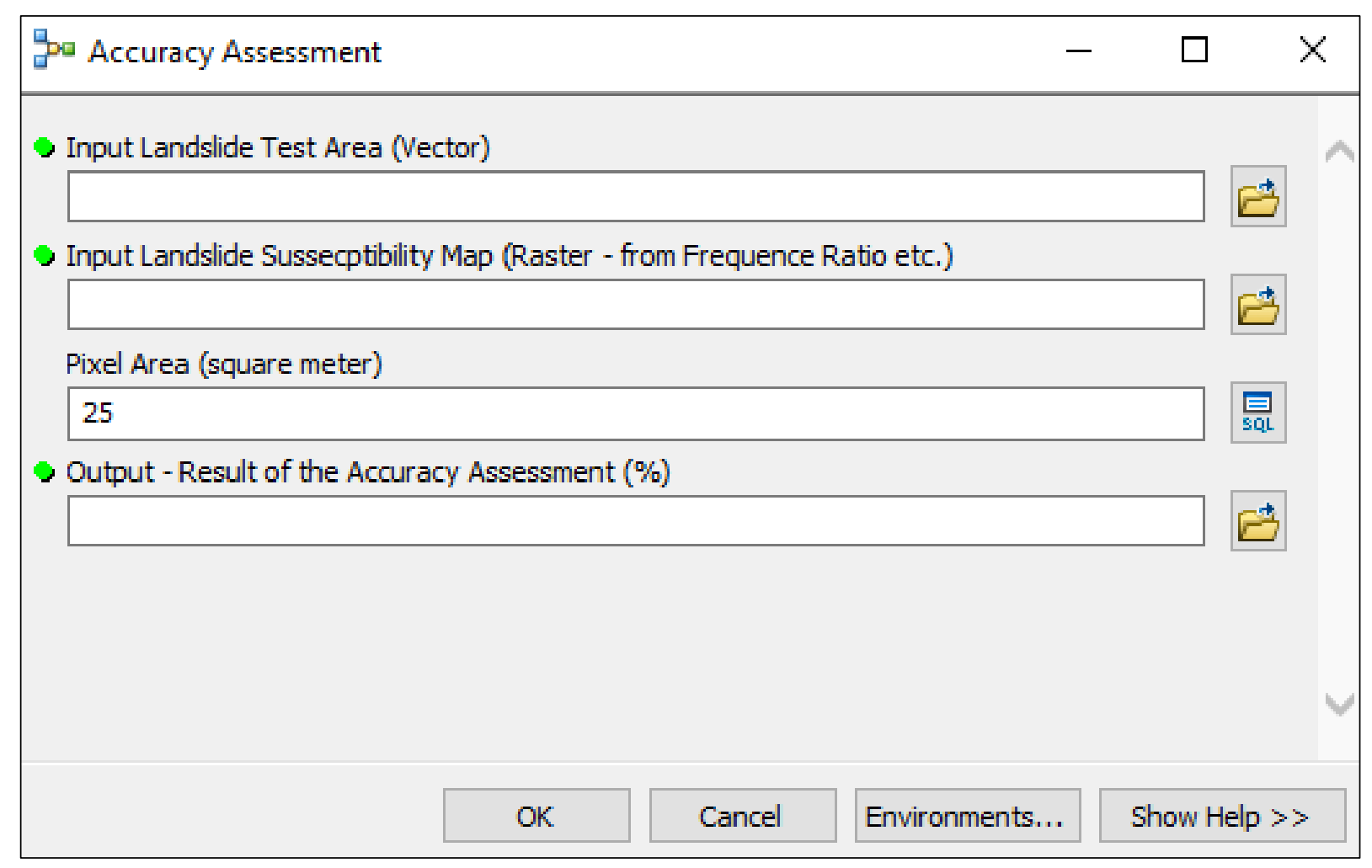

Figure 4. The user interface program developed for accuracy assessment of the LSM

\section{User-interface Programs Developed for}

\section{Producing the LSM and Accuracy Assessment}

The user-interface program (Fig. 3) developed in accordance with 9 parameters considered in the study automatically creates each of these parameter maps by loading the appropriate inputs. For example, the river system is created automatically from the DEM input data, and the buffer zone analysis is automatically performed on it. This includes an application valid for all parameters. Furthermore, the developed userinterface program ensures that all maps are cut according to the same study area and their spatial resolutions are the same with the coordinate system. As it is known, it is essential that the said features of all maps should be same while the latest maps are being overlaid, and the user-interface program

\section{RESULTS AND DISCUSSION}

In this study, the LSM was created by taking into account the slope, aspect, elevation, lithology, distance to fault, distance to river, NDVI, land use and rainfall parameters (9 parameters) and by applying the FR method (Fig. 5).

According to the results obtained, high and very high landslide areas were found to be consistent along the fault and river line. The maximum landslide risk was observed in clastics and provides it. The user-interface program was developed so that the values obtained with the FR and other similar methods (such as WOFE) after creating all the maps could be entered into the system with reclassification as input. This allows that the developed user-interface program could be used for similar methods (WOFE, etc.) except for the FR method. In addition to the LSM-producing user-interface program, a user-interface program calculating the accuracy of this map was also developed (Fig. 4). The inputs of the program are the existing landslide areas in the study area with the LSM obtained as an output from the previous model.

carbonate formations along with the volcanite and sedimentary rocks from the lithological units (upper middle Eocene). On the other hand, this study confirms the statement of Gökçe et al. [1] that the Eocene volcanites in the Eastern Black Sea region are suitable areas for the formation of landslides. When the land use was taken into account, it was observed that the risk of the landslide increased in agricultural and 
Fully-automatic landslide susceptibility analysis by geographical information system (gis): ...

residential areas with a high human effect. The high landslide risk was also determined on the slopes facing moderately sloping northeast with increased moderate elevation. It was indicated by Terrarona et al. [16] in landslide susceptibility analysis studies that the rainfall is also an important triggering factor. According to the findings obtained in this study, the maximum landslide risk was found in areas with the highest average rainfall, and the opinions of Terrarona et al. [16] were also confirmed. The accuracy of the LSMs directly affects the accuracy of each study (urban planning, disaster management, etc.) to be carried out depending on these maps. Therefore, the accurate production of LSMs is extremely important.

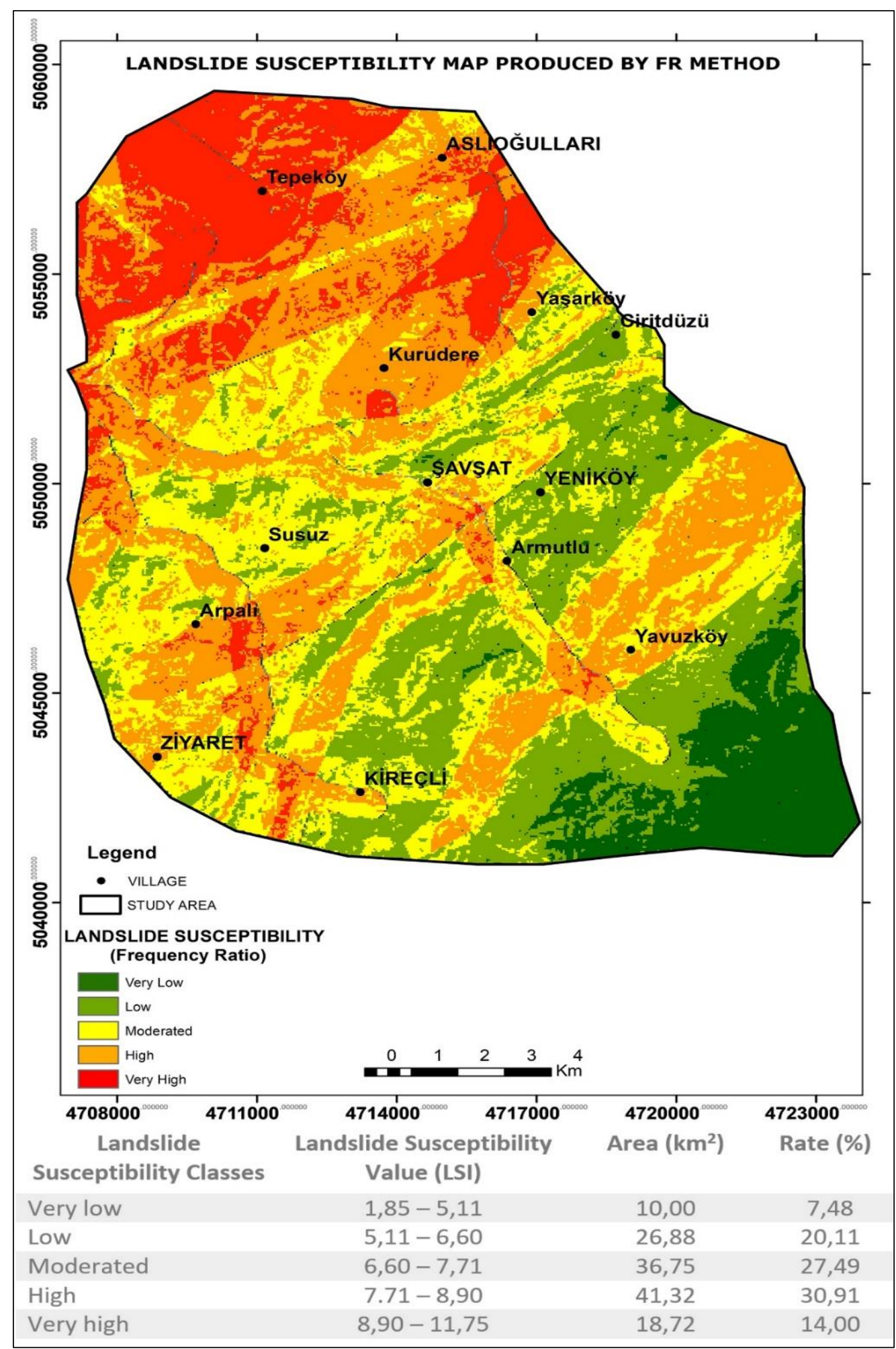

Figure 5. LSM produced by the FR method 
The accuracy of the LSM produced in this study was obtained to be $89 \%$. This accuracy value obtained is consistent with other similar studies in the literature. User-interface programs that can be used easily by everyone, that fully-automatically produce the LSM with the required 9 parameters in

\section{CONCLUSION}

In this study, as it has been emphasized by many researchers in the literature, the FR method has been used for the LSM production since it is easy to apply and provides higher accuracy. With the developed method, the LSM of the study area in Şavşat district of Artvin (Turkey) province was determined fully automatically with $89 \%$ accuracy. On the other hand, this study is the first LSM of Şavşat district produced by the FR method using 9 parameters. Besides, it was ensured that the any landslide area and that fully-automatically calculate the accuracy of this map produced were used for the landslide susceptibility analysis. Thus, it was ensured that long-lasting complex geographic investigation and analysis operations were performed easily.

landslide susceptibility analysis in any location of the world could be easily performed with userinterface programs developed in the GIS environment. After the data related to the parameters used have been added to the userinterface program as the input data, the LSM is fullautomatically produced within a few minutes, and the accuracy of this LSM is determined. When it is considered from this point of view, this study has originality.

\section{REFERENCES}

[1] Gökçe, O., Özden, S. \& Demir, A., Türkiye'de Afetlerin Mekânsal ve İstatistiksel Dağılımı Afet Bilgileri Envanteri, Bayındırlık ve İskân Bakanlığı Afet İşleri Genel Müdürlüğü, Afet Etüt ve Hasar Tespit Daire Başkanlı̆̆ı, Ankara, 2008 .

[2] Reis, S., Yalçın, A., Atasoy, M., Nişancı, R., Bayrak, T., Sancar C., \& Ekercin, S, CBS ve Uzaktan Algılama Teknikleri ile Heyelan Duyarlılık Haritalarının Üretimi: Rize İli Örneği, Türkiye Ulusal Fotogrametri Ve Uzaktan Algılama Birliği V. Teknik Sempozyumu, Ankara, 2009.

[3] Varnes, D. J., Landslide hazard zonation: A review of principles and practices commision on landslides of the IAEG, UNESCO, Paris, 1984.

[4] Kavzoglu,T., Şahin, E.K., \& Çölkesen, İ., CBS Tabanlı Çok Kriterli Karar Analizi Yöntemiyle Heyelan Duyarlılık Haritasının Üretilmesi: Trabzon İli Örneği, 3. Uzaktan Algılama ve Coğrafi Bilgi Sistemleri Sempozyumu, Gebze, Kocaeli, 2010.

[5] Boroushaki, S. and Malczewski, J., Implementing an Extension of The Analytical Hierarchy Process Using Ordered Weighted Averaging Operators with Fuzzy Quantifiers in Arcgis, Computers \& Geosciences, 34, 399-410, 2008.

[6] Erener, A., \& Lacasse, S., Landslide susceptibility mapping using GIS, 28th Asian Conference on Remote Sensing ACRS 2007, Kuala Lumpur, Malesia.

[7] Kavzoglu, T., Şahin, E, K., \& Colkesen, I., Heyelan duyarlılığının incelenmesinde regresyon ağaçlarının kullanımı:Trabzon örneği, Harita Dergisi, 147, 21-33, 2012.

[8] Erener, A., Mutlu, A., \& Duzgun, H.S., A Comparative study for landslide susceptibility mapping using GIS-based multi-criteria decision analysis (MCDA), logistic regression (LR) and association rule mining (ARM), Engineering Geology, 203, 45-55, 2017.

[9] Colkesen, I., Sahin, K.E., \& Kavzoglu, T., Susceptibility Mapping of Shallow Landslides Using Kernel-Based Gaussian Process, Support Vector Machines and Logistic Regression, Journal of African Earth Sciences 118, 53-64, 2016.

[10] Chen, W., Xie, X., Peng, J. W., Duan, Z., \& Hong, H., GIS-based landslide susceptibility modelling: a comparative assessment of kernel logistic regression, Naïve-Bayes tree, and alternating decision tree models, Geomatics, Natural Hazards and Risk, 1947-5705, 2017.

[11] Guzzetti, F., Carrara, A., Cardinali, M., \& Reichenbach, P., Landslide hazard evaluation: A review of current techniques and their application in a multi-scale study, Central Italy, Geomorphology, 31, 181-216, 1999.

[12] Duman, t. Y., Can, T., Gokceoglu, C., Nefeslioglu, H.A., \& Sonmez, H., Application of logistic regression for landslide susceptibility zoning of Cekmece Area, Istanbul, Turkey, Environ Geol, 51: 241-256, 2006.

[13] Nandi, A., \& Shakoor, A., A GIS- based landslide susceptibility evalution using bivariate and multivariate statistical analyses, Engineering Geology 110, 11-20, 2009.

[14] Bai, S.B., Lu, G.N., Wang, J.A., Zhou, P.G., \& Ding, L.A., GIS-based Rare Events Logistic Regression for Landslide-Susceptibility Mapping of Lianyungang, China, Environmental Earth Sciences, 62, 139-149, 2011.

[15] Dai, F.C., \& Lee, C.F., Landslide Characteristics and, Slope Instability Modeling Using GIS, Lantau Island, Hong Kong. Geomorphology, 42, 213-228, 2002. 
[16] Terranova, O.G., Gariano, S.L., Bruno, C., Greco, R., Pellegrino A.D., \& Lovine, G.G.R., Landslide-risk scenario of the Costa Viola mountain ridge (Calabria, Southern Italy), Journal of Maps, Vol. 12, No. S1, 261-270, 2016.

[17] Lee, S., \& Talib, J. A., Probabilistic landslide susceptibility and factor effect analysis, Environ Geol 47: 982-990, 2005.

[18] Yilmaz, I., Landslide susceptibility mapping using frequency ratio, logistic regression, artificial neural networks and their comparison: A case study from Kat landslides (Tokat -Turkey), Computer and Geosciences, 35, 1125-1138, 2009.

[19] Lee, S., \& Pradhan, B., Probabilistic landslide hazards and risk mapping on Penang Island, Malaysia, Earth system science, 115 (6), 661-672, 2006.

[20] Duman, T.Y., T. Çan \& Ö. Emre, 1/1.500.000 Türkiye Heyelan Envanteri Haritası, Maden Tetkik ve Arama Genel Müdürlüğü Özel Yayınlar Serisi -27, Ankara, Türkiye. ISBN:978-605-4075-85-3, 2011.

[21] Pachauri, A. K., Gupta, P. V. \& Chander, R., Landslide zoning in a part of the Garhwal Himalayas, Environmental Geology, 36, 325-334, 1998.

[22] Ercanoğlu, M., Gökçeoğlu, C., \& Van Asch, Th.W.J., Landslide Susceptibility Zoning North of Yenice (NW Turkey) by Multivariate Statistical Techniques, Natural Hazards, 32: 1-23, 2004.

[23] Altural, T., Coğrafi Bilgi Sistemiyle Akşehir (Konya) Çevresinin Heyelan Duyarlılık İncelenmesi, Yüksek Lisan Tezi, Selçuk Üniversitesi Fen Bilimleri Enstitüsü Jeoloji Mühendisliği Anabilim Dalı, Konya, 2012.

[24] Ö. Emre, Duman, T.Y., Özalp, S., Elmac1, H., Olgun, Ş. \& Şaroğlu, F., 1/1.125.000 Ölçekli Türkiye Diri Fay Haritası, Maden Tetkik ve Arama Genel Müdürlüğü Özel Yayınlar Serisi-, Ankara, Türkiye, 2013.

[25] Gökçeoglu, C., \& Aksoy, H., Landslide susceptibility mapping of the slopes in the Residuel soils of the Mengen region (Turkey) by deterministic stability analyses and image processing techniques, Engineering Geology, 44, 147-161, 1996.

[26] Saha, A.K., Gupta, R.P., \& Arora, M.K., GIS-based Landslide Hazard Zonation in the Bhagirathi (Ganga) Valley, Himalayas, International Journal of Remote Sensing, 23(2), 357-369, 2002.

[27] Gökçeoğlu, C. \& Ercanoğlu, M., Heyelan duyarlılık haritalarının hazırlanmasında kullanılan parametrelere ilişkin belirsizlikler, Hacettepe Üniv. Yerbilimleri Uygulama ve Araştırma Merkezi Bülteni, Yerbilimleri, 23, 189-206, 2001. 